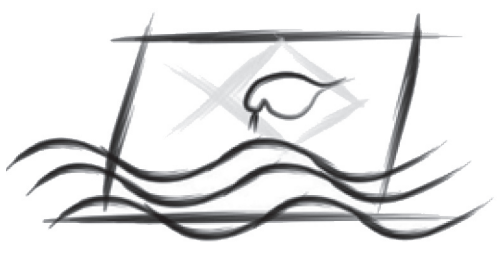

J. Braz. Soc. Ecotoxicol., v. 5, n. 1, 2010, 41-47

doi: 10.5132/jbse.2010.01.007

ECOTOX - Brazil

\title{
Organochlorine Compounds in Common Carp (Cyprinus carpio) from Patagonia Argentina
}

\author{
P. M. Ondarza ${ }^{1,2}$, K. S. B. Miglioranza ${ }^{1,2}$, M. Gonzalez ${ }^{1,2}$, V. M. Shimabukuro ${ }^{1}$, J. E. Aizpún ${ }^{1}$ \& V. J. Moreno ${ }^{1 *}$ \\ ${ }^{1}$ Laboratorio de Ecotoxicología, Facultad de Ciencias Exactas y Naturales, \\ Universidad Nacional de Mar del Plata, Funes, 3350, CP 7600, Mar del Plata, Argentina \\ ${ }^{2}$ Consejo Nacional de Investigaciones Científicas y Técnicas - CONICET, \\ Avda. Rivadavia 1917 - CP C1033AAJ - Cdad. de Buenos Aires
}

(Received April 28, 2008; Accepted August 7, 2009)

\begin{abstract}
The Negro River is the most important hydrological system of Patagonia, Argentina, drains a watershed of $140,000 \mathrm{~km}^{2}$. Its main economic activities are agriculture and industry, representing potential sources of organochlorine compounds (OCCs): organochlorine pesticides (OCPs) and PCBs, respectively. These pollutants are persistent, ubiquitous and hydrophobics and are accumulated in the lipid fraction of biota. Fish are excellent biomonitors of pollution because incorporate COCs from water and through diet, and represent different trophic levels. The aims of the present study were to investigate OCCs levels in wild common carp, Cyprinus carpio (Cyprynidae) focusing on: a) the distribution pattern of OCPs and PCBs in gills, gonads, liver, muscle, and stomach content, b) the potential of common carp as indicator of aquatic OCCs pollution, and c) the evaluation of residues in gills and stomach content to discuss different input pathways of OCCs.

HCHs, Chlordanes, DDTs, Endosulfan, Heptachlors, Drines and PCBs were quantified by GC-ECD. The distribution of OCCs (ng. $\mathrm{g}^{-1}$ lipid) was gills $>$ gonads $>$ liver $>$ muscle $>$ stomach content. Endosulfan accounted for $64 \%$ of OCCs in gills while, DDTs, PCBs and Chlordanes predominated in the stomach content suggesting the incorporation of more hydrophilic pollutants from the water column and those most persistent and hydrophobic from the diet.
\end{abstract}

Keywords: organochlorine pesticides, PCBs, fish, common carp, bioindicator, respiration and dietary uptake, Patagonia Argentina.

\section{RESUMEN}

\section{Compuestos Organoclorados en Carpa Común (Cyprinus carpio) Provenientes de Río Negro, Patagonia, Argentina}

El Río Negro es el sistema hidrológico más importante de la Patagonia Argentina, drena una cuenca de $140.000 \mathrm{Km}^{2}$. Sus principales actividades económicas son la agricultura y la industria, representando áreas potenciales de emisión de compuestos organoclorados (COCs): plaguicidas organoclorados (POCs) y PCBs, respectivamente. Estos contaminantes son persistentes, ubicuos e hidrofóbicos, acumulándose en los lípidos de la biota. Los peces son excelentes bioindicadores de contaminación ya que incorporan COCs desde el alimento y/o agua, ocupan distintos niveles tróficos y permiten determinar niveles traza en sus tejidos. Se determinó la distribución de COCs en branquias, músculo, hígado, gónadas y contenido estomacal de carpa común (Cyprinus carpio) de Río Negro. Además, se evaluaron posibles vías de ingreso de COCs por medio del estudio comparativo de residuos en branquias y contenido estomacal. Los POCs (HCHs, Clordanos, DDTs, Endosulfanes, Heptacloros, Drines) y PCBs fueron cuantificados por GC-ECD. La distribución de COCs (ng. g $^{-1}$ lípido) presentó el siguiente gradiente: branquias > gónadas $>$ hígado >músculo >contenido estomacal. Endosulfanes representaron el $64 \%$ de los COCs en branquias mientras que, DDTs, Clordanos y PCBs predominaron en el contenido estomacal sugiriendo la incorporación de contaminantes más hidrofílicos desde la columna de agua y aquellos más persistentes e hidrofóbicos desde la dieta.

Palabras clave: compuestos organoclorados, PCBs, peces, carpa común, bioindicador, vías de ingreso, Patagonia Argentina.

* Corresponding author: Paola Ondarza, e-mail: pmondar@mdp.edu.ar

This work was presented in X Congress ECOTOX, Bento Gonçalves - Puerto Alegre, Brasil 


\section{INTRODUCTION}

Organochlorine pesticides (OCPs) and polychlorinated biphenyls (PCBs) integrate the organochlorine compounds group (OCCs). They are responsible of relevant environmental contamination representing potential risks to both, human health and the environment. Although, PCBs and OCPs have been worldwide used for industrial and agricultural purpose, respectively, most of them are currently forbidden with the exception of Endosulfan pesticide. Their physicochemical properties, such as molecular weight, shape, hydrophobicity, vapor pressure and environmental persistence define their behavior and environmental bioavailability. Hence, OCPs and PCBs could reach to non target aquatic environments where they are preferentially sorbed onto dissolved and particulate organic matter or accumulated by biota.

Hydrophobic pollutant assessment in aquatic environment could be done using the potential of biota to accumulate these contaminants in the lipid fraction. Fish are particularly useful because they have a big interaction with water, sediments and macrophytes occupying different habitats and trophic levels. The evaluation of recalcitrant contaminant accumulation in fish tissues, provide an integral view of the aquatic environment pollution and allows predicting the risk exposure for human health (Sánchez et al., 1993). The uptake, distribution, effects and elimination of contaminants in fish are also influenced by different factors such as life history (habitat, food, sex) and physiological condition (lipid composition, spawning and metabolism) of each species.

Mackay \& Fraser (2000) have purposed different uptake and loss mechanisms of OCCs in fish. In one hand, food constitutes the main uptake process while growth dilution, reproductive loss, metabolic conversion, excretion and defecation are loss mechanisms. On the other hand, respiration and dermal diffusion are reversible transfer processes. When uptake exceeds elimination, bioconcentration take place. This process is called bioaccumulation when the source of contaminants is another matrix than water, like sediment or food. Finally, biomagnification occurs when contaminants loads increase significantly with each successive trophic level (Landrum \& Fisher, 1998).

The aims of the present study were to investigate OCCs levels in wild common carp, Cyprinus carpio (Cyprynidae), from the Lower Valley of Negro River, Patagonia Argentina, focusing on:

1. The distribution pattern of OCPs and PCBs in gills, gonads, liver, muscle, and stomach content;

2. The potential of common carp as indicator of aquatic OCCs pollution in their environment; and

3. The evaluation of residues in gills and stomach content to discuss different input pathways of OCCs.

This study represent the first report of OCCs in common carps from the Lower Valley of the Negro River, Patagonia Argentina. This exotic specie was selected because is abundant and easy to caught in the lower flow, omnivorous that feeds preferably on macrophytes and organic matter (Alvear et al. 2007), do not migrate and is currently being incorporated into the diet of inhabitants from the Negro River. Therefore, it is relevant evaluate pesticides residues levels in carp in order to predict both ecological and human risks. Moreover, common carp has been widely used in toxicity and other related test under laboratory experiment while there are few works using wild specimens under field conditions (Nowak et al., 1995; Gerstenberger et al., 1997; van der Oost et al., 1998; Szarek et al., 2000).

\section{MATERIAL AND METHODS}

\section{Study area}

The Negro River, with a basin of $140,000 \mathrm{~km}^{2}$, is the most important hydrographic system of the North of Patagonia, Argentina and runs $720 \mathrm{~km}$ before discharging into the Atlantic Ocean. On the basis of its precipitation regimen, the river is divided into three valleys: Upper, Medium and Lower. The flow of about $1000 \mathrm{~m}^{3} \cdot \mathrm{s}^{-1}$ is regulated by up stream dams. The river provides water for domestic, industrial and agriculture uses through an irrigation system. The area supports an intensive exploitation relative to fruit production, urban settlements and industrial activities. Therefore, the river is subject to agrochemical runoff and also receives inputs from urban and industrial effluents without pre-treatment (Arribére et al., 2003).

\section{Sampling procedure}

Carps were caught with gill nets directly from the irrigation system in the Lower Valley of the Negro River $\left(40^{\circ} 51^{\prime} \mathrm{S}\right.$ and $\left.62^{\circ} 57^{\prime} \mathrm{W}\right)$, in October of 2006 . After that, each fish was immediately frozen at $-20^{\circ} \mathrm{C}$. At the laboratory, the specie was identified using a taxonomy key, total weight and length were recorded and sex and reproductive stages were macroscopically determined. Five individuals of similar weight and length were dissected in order to obtain the dorsal muscle tissue, liver, gonads, gills and stomach content. Moreover, the condition $\left(\mathrm{KI}=\right.$ total weight $\left.(\mathrm{g}) /(\text { total length })^{3}(\mathrm{~cm})\right)$, hepatic $(\mathrm{HI}=$ liver weight $(\mathrm{g}) /$ total weight $(\mathrm{g}) \times 100)$ and gonadal indexes $(\mathrm{GI}=$ gonad weight $(\mathrm{g}) /$ total weight $(\mathrm{g}) \times 100)$ were calculated. All tissues samples from each fish were homogenized and analyzed by duplicate. The biomagnification factor (BMF) was calculated as mean concentration in carp muscle/ mean concentration of stomach content using lipid-normalized data.

\section{Age determination}

Groups of ages were defined through out the lecture of bone elements: otoliths and scales. In each fish, four scales (not regenerated) were extracted from the right and left side, upper the lateral line and just after the opercula. Under binocular optic microscopy, the total ratio of each scale was measured and the annulis were counted.

\section{Organochlorine compounds (OCCs) analysis}

Extraction and clean up: Subsamples of $5 \mathrm{~g}$ for muscle and $3 \mathrm{~g}$ for liver, gonads, gills and stomach content, were mixed with anhydrous $\mathrm{Na}_{2} \mathrm{SO}_{4}$ and extracted (50:50 hexane:methylene chloride) during 6 hours using Soxhlet method. Extracts were 
concentrated using a vacuum bomb and under nitrogen flow at $3 \mathrm{~mL}$. Gel Permeation Chromatography using Bio Beeds S-X3 (200-400 mesh), was used for lipid and OCCs separation. Thus, total lipid content was determined by gravimetric method $(0.0001 \mathrm{~g}$ precision). The OCCs fraction was collected, concentrated to $2 \mathrm{~mL}$ and fractionated, by Silica Gel Chromatography, in Organochlorine Pesticides (OCPs) and Biphenyl Polychlorinated (PCBs) (Metcalfe T. L.; Metcalfe, C. D., 1997).

Quantification of OCPs and PCBs: The contaminants analyzed were: OCPs: $\mathrm{HCHs}(\alpha-, \beta-, \gamma$ - and $\delta$ - isomers), Chlordanes ( $\alpha$ - and $\gamma$ - isomers and trans-nonachlor), DDTs (pp'-DDE, pp'-DDD and pp'-DDT), Endosulfan ( $\alpha$-, $\beta$ - isomers and Endosulfan sulfate), Heptachlors (Heptachlor and Heptachlor epoxide) and Drins (Aldrin, Dieldrin and Endrin). PCBs: IUPAC·\# 8, 18, 28, 52, 44, 66, 101, 87, 110, 149, 118, 153, $105,138,126,187,128,167,156,157,180,169,170,189$, 195, 206, 209.

Determination was done using a Shimadzu 17-A Gas Chromatography with ${ }^{63} \mathrm{Ni}$ Electron Capture Detector (GC-ECD) equipped with a fused-silica capillar column of $30 \mathrm{~m}$ Supelco SPB-5 (0.25 mm i.d., $0.25 \mu \mathrm{m}$ film thickness). The injection volume was $1 \mu \mathrm{L}$ with a splitless injection mode, at $275^{\circ} \mathrm{C}$. The ECD temperature was $290^{\circ} \mathrm{C}$. The following temperature program was applied: start at $100{ }^{\circ} \mathrm{C}$ and held for 1 minute, followed by an increase of $5{ }^{\circ} \mathrm{C} \cdot \mathrm{min}^{-1}$ up to $150{ }^{\circ} \mathrm{C}$, held for 1 minute, then $1.5^{\circ} \mathrm{C} \cdot \mathrm{min}^{-1}$ up to $240^{\circ} \mathrm{C}$, and then $10^{\circ} \mathrm{C} \cdot \mathrm{min}^{-1}$ up to $300{ }^{\circ} \mathrm{C}$ for 10 minutes. Ultra-high purity Helium was used as carrier gas $\left(1.5 \mathrm{~mL} \cdot \mathrm{min}^{-1}\right)$ and nitrogen as make-up (Miglioranza et al. 2003).

Quantification was carried out with internal (PCB \#103) (Ultra Scientific, RI, USA) and external standards (Absolute Standards, INC, CT, USA). Laboratory quality assurance samples were used to estimate the quality of the analytical data. Laboratory quality control consisted in a matrix blank analyzed every eighth samples with each extraction set and surrogate recovery spikes. Results of laboratory blanks indicate that, samples were not contaminated due to the processing in the laboratory. The spiked surrogate recovery was between $80 \%$ and $110 \%$. Detection limit ranged between $0.03-0.05$ for HCHs and between $0.08-0.33$ ng. $\mathrm{g}^{-1}$ wet weight $(\mathrm{w} w \mathrm{wt}$ ) for the rest of compounds.

\section{Data expression and statistic analysis}

Each date corresponds to the arithmetic mean of 10 individual determinations. Concentrations are reported on a wet weight basis and additionally normalized to lipid content in all fish tissues.
Since concentrations of OCCs in tissues are not independent, statistical differences between gills, liver, muscle, gonads and stomach content were tested using a Friedman ANOVA analysis for multiple dependent samples. Comparisons were made using a Wilcoxon matched pair test. The significance level was set at $\alpha=0.05$ (Zar, 1984) and it is specified in the text when differences were found at a level of $\alpha=0.1$ or 0.01 .

\section{RESULTS}

\section{Biological characteristics}

Table 1 shows the biological characteristics of common carp from Negro River. The carps analyzed had similar size ranging the total weight $(\mathrm{g})$ and total length $(\mathrm{cm})$ between 493.96-232.69 and 29.5-23.5, respectively. All the individuals were females with $1+$ and $2+$ years. The KI were higher than 1 while values of HI and GI ranged between 0.5-1.9 and $0.1-2.9$, respectively.

\section{Relation between the total lipids content and the total OCCs concentrations (ng. $\mathrm{g}^{-1} \mathrm{w}$ wt)}

The highest and the lowest total lipid content were found in liver and muscle (3.94 and $0.83 \%$, respectively). Our results show a positive correlation between total lipid percentage and OCPs concentration (ng. $\left.\mathrm{g}^{-1} \mathrm{w} w \mathrm{w}\right)$ in gills $\left(\mathrm{r}^{2}=0.4, \mathrm{p}<0.05\right)$, gonads $\left(\mathrm{r}^{2}=0.8, \mathrm{p}<0.05\right)$, liver $\left(\mathrm{r}^{2}=0.17, \mathrm{p}<0.05\right)$, muscle $\left(\mathrm{r}^{2}=0.38, \mathrm{p}<0.05\right)$ and stomach content $\left(\mathrm{r}^{2}=0.53, \mathrm{p}<0.05\right)$. However, PCBs levels only showed a positive correlation with the lipid content in gonads and muscle $\left(r^{2}=0.63\right.$ and $r^{2}=0.19$ $\mathrm{p}<0.05$, respectively).

\section{Total OCCs distribution in fish tissues (ng. ${ }^{-1}$ lipid)}

The total OCCs levels in gills were one order of magnitude higher than in the other tissues leading to the following order: gills $\gg>$ gonads $>$ muscle $>$ liver $>$ stomach content with significant differences between gills, muscle, liver and stomach content (ANOVA Friedman $\mathrm{p}<0.05$ ) (Table 2).

\section{OCPs groups and PCBs distribution (ng. ${ }^{-1}$ lipid)}

\section{Endosulfan}

The highest total Endosulfan levels were found in gills representing $68 \%$ of the total pesticides residues with significant differences among muscle (ANOVA Friedman $\mathrm{p}<0.05$ ), liver

Table 1 - Total length and weight, sex, age, KI, HI and GI.

\begin{tabular}{cclccccccc}
\hline Individual & TL $(\mathrm{cm})$ & TW $(\mathrm{g})$ & Sex/RE & Age & Liver $(\mathrm{g})$ & Gonad $(\mathrm{g})$ & KI & HI & GI \\
\hline 1 & 29.5 & 493.96 & F/1 & $2+$ & 2.95 & 5.35 & 1.9 & 0.6 & 1.1 \\
2 & 29.6 & 438.88 & F/2 & $2+$ & 5.28 & 12.83 & 1.7 & 1.2 & 2.9 \\
3 & 27.7 & 361.63 & F/1 & $1+$ & 5.12 & 1.31 & 1.7 & 1.4 & 0.4 \\
4 & 26.5 & 314.7 & F/1 & $1+$ & 1.48 & 0.44 & 1.7 & 0.5 & 0.1 \\
5 & 23.5 & 232.69 & F/1 & $1+$ & 4.41 & - & 1.8 & 1.9 & - \\
\hline
\end{tabular}

TL: Total Length, TW: Total Weight, F: Female, RE: Reproductive stages, KI: Condition Index, HI: Hepatic Index, GI: Gonadal Index. 
and stomach content (ANOVA Friedman $\mathrm{p}<0.01$ ). Moreover, in gills Endosulfan sulfate account for the $82.5 \%$ of the group (ANOVA Friedman, Wilcoxon $p<0.01$ ). The $\alpha$-/ $\beta$ - isomers ratio was higher to 1 ranging from 1.1 to 7 (stomach content and muscle, respectively) in all tissues.

\section{DDTs}

Gills and gonads presented the highest levels of this group (not significant difference). The DDTs contribution to total OCCs was more important in gonads (40\%), liver (21\%) and stomach content (20\%) conversely to that observed in gills $(12 \%)$ (ANOVA Friedman $\mathrm{p}<0.05$ ). The pp'-DDE/pp'-DDT relation was higher to 1 in all tissues with the maximum value equal to 64 in gonads.

\section{Chlordanes}

The highest Chlordanes concentrations were found in gills (ANOVA Friedman $\mathrm{p}<0.05$ ). However, they represent only $10 \%$ of the total contaminants levels in this tissue at difference of stomach content, liver and gonads where Chlordanes represents 20, 17 and 16\% of total OCCs, respectively. Gamma chlordane level was significantly higher than $\alpha$-isomer in all tissues (ANOVA Friedman $\mathrm{p}<0.05$ ).

\section{HCHs}

Hexachlorocyclohexanes was mainly represented by $\gamma$-isomer while $\beta$ - and $\delta$ - levels were below the detection limit in all tissues. HCHs levels in muscle were significantly lower than in gills and liver (ANOVA Friedman $p<0.05$ ) however, this group of pesticide accounting $26 \%$ of the total OCCs in stomach content.

\section{Heptachlors}

The metabolite Heptachlor epoxide was the main residue of the group. Moreover, it was the unique residue found in gills being one order of magnitude higher than in the other tissues. In gonads, both Heptachlor and H. epoxide levels were below the detection limit.

\section{Drins}

This group had the lowest level of the total OCPs in all tissues and Dieldrin was the unique compound with levels above the detection limit (except in muscle). Significant differences in Dieldrin levels among gills versus muscle and stomach content (ANOVA Friedman $p<0.05$ and $p<0.1$, respectively) were observed.

\section{PCBs}

Tissue distribution of PCBs showed the following distribution: gills $>$ muscle $>$ liver $>$ stomach content $>$ gonads . PCBs concentrations in gills were significant different than those in muscle and gonads (ANOVA Friedman $\mathrm{p}<0.1$ ). Moreover, stomach content levels were significant different from liver, gills and muscle (ANOVA Friedman $p<0.05$ ). Congeners with 4, 5 and 6 chlorine atoms were quantitatively more important in all tissues with predominance of \# 44, 87, 101, 110, 138 and 153.

Table 2 - Individual OCPs and total PCBs concentrations (mean \pm standard deviation) (ng.g ${ }^{-1}$ lipid) in tissues of common carp.

\begin{tabular}{|c|c|c|c|c|c|}
\hline & Gills & Gonads & Liver & Muscle & Stomach content \\
\hline$\%$ lipids & 2.27 & 2.69 & 3.94 & 0.83 & 1.71 \\
\hline$\alpha$ Endosulfan & $154.95 \pm 225.7^{\mathrm{b}}$ & $108.20 \pm 174.9^{b}$ & $55.38 \pm 58$ & $135.56 \pm 372.7$ & $10.99 \pm 7.6$ \\
\hline$\beta$ Endosulfan & $101.03 \pm 73.19^{\mathrm{b}}$ & $44.66 \pm 49.8^{\mathrm{b}}$ & $38.31 \pm 32.1$ & $19.27 \pm 25.5$ & $9.21 \pm 8.6$ \\
\hline E. sulfate & $1,206.72 \pm 1538.4^{\mathrm{a}}$ & $59.17 \pm 82.2^{\mathrm{b}}$ & $18.07 \pm 187.8$ & $16.53 \pm 11.7$ & $3.91 \pm 3.2$ \\
\hline pp'-DDE & $132.47 \pm 150.8^{\mathrm{a}}$ & $232.39 \pm 407.8^{\mathrm{a}}$ & $60.07 \pm 103.9$ & $17.47 \pm 19.5$ & $24.83 \pm 22.9$ \\
\hline pp'-DDD & $27.48 \pm 37.7^{\mathrm{b}}$ & $1.50 \pm 1.9^{\mathrm{b}}$ & $4.81 \pm 8.7$ & $4.42 \pm 4.8$ & $1.24 \pm 1.3$ \\
\hline pp'-DDT & $111.71 \pm 105.9^{\mathrm{b}}$ & $3.62 \pm 5.2^{\mathrm{b}}$ & $13.08 \pm 20.9$ & $13.33 \pm 6.6$ & $4.46 \pm 4.8$ \\
\hline$\gamma$ Chlordane & $171.07 \pm 107.8^{\mathrm{a}}$ & $64.01 \pm 63.9^{\mathrm{a}}$ & $43.15 \pm 44.9$ & $44.06 \pm 23.9$ & $23.97 \pm 16.8$ \\
\hline$\alpha$ Chlordane & $49.77 \pm 33.8^{\mathrm{b}}$ & $24.56 \pm 28.8^{\mathrm{b}}$ & $10.89 \pm 8.3$ & $12.53 \pm 7.7$ & $6.00 \pm 4.7$ \\
\hline Trans-nonachlor & $5.70 \pm 11.1^{\mathrm{b}}$ & $4.85 \pm 6.7^{\mathrm{b}}$ & $6.00 \pm 6.5$ & $7.67 \pm 8.1$ & $1.71 \pm 3.2$ \\
\hline$\alpha \mathrm{HCH}$ & $<\mathrm{LD}$ & $<\mathrm{LD}$ & $0.09 \pm 0.2$ & $<\mathrm{LD}$ & $0.20 \pm 0.4$ \\
\hline$\beta \mathrm{HCH}$ & $<\mathrm{LD}$ & $<\mathrm{LD}$ & $<\mathrm{LD}$ & $<\mathrm{LD}$ & $<\mathrm{LD}$ \\
\hline$\gamma \mathrm{HCH}$ & $62.02 \pm 44.5$ & $26.71 \pm 31.6$ & $29.65 \pm 21.3$ & $14.42 \pm 9.8$ & $43.67 \pm 34.7$ \\
\hline$\delta \mathrm{HCH}$ & $<\mathrm{LD}$ & $<\mathrm{LD}$ & $<\mathrm{LD}$ & $<\mathrm{LD}$ & $<\mathrm{LD}$ \\
\hline Heptachlor & $<\mathrm{LD}$ & $<\mathrm{LD}$ & $0.24 \pm 0.5$ & $0.39 \pm 0.8$ & $<\mathrm{LD}$ \\
\hline H. Epoxide & $88.60 \pm 127.7$ & $<\mathrm{LD}$ & $24.94 \pm 44.1$ & $18.21 \pm 20.8$ & $12.60 \pm 23.1$ \\
\hline Aldrin & $<\mathrm{LD}$ & $<\mathrm{LD}$ & $<\mathrm{LD}$ & $0.31 \pm 0.6$ & $<\mathrm{LD}$ \\
\hline Dieldrin & $50.62 \pm 42.3$ & $10.09 \pm 15.2$ & $11.24 \pm 19.7$ & $5.81 \pm 7.6$ & $8.75 \pm 10.4$ \\
\hline Endrin & $<\mathrm{LD}$ & $<\mathrm{LD}$ & $<\mathrm{LD}$ & $<\mathrm{LD}$ & $<\mathrm{LD}$ \\
\hline Total PCBs & $139.31 \pm 118.9^{b}$ & $6.9 \pm 14.8^{\mathrm{a}}$ & $38.46 \pm 52.6^{\mathrm{a}}$ & $102.58 \pm 134.7^{b}$ & $14.53 \pm 8.7^{\mathrm{a}}$ \\
\hline
\end{tabular}

$<\mathrm{LD}$ - below of detection limit; Total PCBs $=\sum(\# 18,52,44,66,87,110,149,118,153,105,138,126,187,180,156,196)$. Means not sharing the same superscript ( $\mathrm{a}$ or $\mathrm{b}$ ) within groups for each tissue (column) are significantly different at $\mathrm{p}<0.05$ (gonads and stomach content) and $\mathrm{p}<0.01$ (gills, liver and muscle). 


\section{DISCUSSION}

In natural environments, fishes are exposed to a wide range of organic contaminants which have different behavior in function of its physicochemical properties. Thus, OCPs and PCBs could be adsorbed onto bottom sediments and suspended particular matter, dissolved in the water column and accumulated in biota. The response of fishes to these toxic substances depends on compounds concentration and bioavailability as well as on the biology and ecology of the specie. Therefore, fishes are good indicators for monitoring aquatic pollution.

Usually, the KI is accepted as a quantitative indicator of the general health of fish. The values higher to 1 found in common carp females showed a relative good condition of the organisms. On the other hand, both HI and GI represented the percentage of these organs respect to the total fish weight. Both indexes showed a wide range of values as a consequence of the lipid distribution in the organism in relation to their physiological condition such as reproductive stage.

OCCs are mainly bioaccumulated in lipid fraction of fishes therefore we determined correlations between total lipids fraction and contaminants levels. The high correlation found in gonads is consistent with the lipid mobilization from the whole body during pre-spawning period in females. Besides, differences in correlation of total lipids and OCCs among tissues could be in relation to different lipid composition considering polar and non-polar fractions. Eldkus et al. (2005) reported that for partitioning of highly hydrophobic contaminants, such as PCBs, triacylglycerols (non-polar) are better predictors than the total lipids. In order to corroborate the previous statement, studies about the composition of polar and non-polar lipids and fatty acids fractions in different tissues of fish are being carried out. Moreover, in relative lean tissues non-lipid components, such as proteins, could be involved in the absorption of the contaminants (Bertelsen et al., 1998).

On the basis of the lower lipid content presented in muscle $(0.83 \%)$, carp is considered a lean fish in comparison with other edible specie inhabiting the same environment, the Negro River, like rainbow trout Oncorhynchus mykiss (3.68\%) (Ondarza et al., 2007). OCPs levels in muscle were below the maximum limits of residues in food for used and forbidden pesticides (MRL and EMRL, respectively, FAO/WHO Codex Alimentarius, 2001). These results suggest that there are not risks for the habitants of the Negro River. Considering the persistence of these contaminants and their levels it would be necessary to develop a periodic monitoring program of OCPs in carps muscle as well other environmental matrixes to asses temporal trends. The final goal of this program should be settled in order to prevent or reduce risk to human being and preserve environmental quality.

The Lower Valley of Negro River constitutes an important fruit growing zone in Argentina. Apple, pears, peaches and citrus production supplies both local and international market (exportation about US\$50 million/year) (www.spi.rionegro. gov.ar). Thus, pesticides from historical or current uses can persist and being distributed with the potential risk for the Negro River environment. The highest OCPs levels found in all fish tissues support this statement.
Considering that respiration represents a transference input pathway to contaminants, the contribution of the water column as a source of OCCs through the gills in common carp was discussed. Total levels of OCCs in gills were one order of magnitude higher than in the other tissues showing that OCCs uptake from the water column is an important input pathway to fishes. Endosulfan is the unique organochlorine pesticide which application is permitted and suggested by Instituto Nacional de Tecnología Agropecuaria (INTA) in Argentina (INTA, 2004). After technical mixture application $(\alpha: \beta=70: 30)$, due to their physicochemical characteristics, the $\alpha$ - isomer will be loss more quickly than $\beta$ - therefore; the $\alpha-\beta$ - ratio allows the estimation of Endosulfan application (Schmidt et al., 1997). Thus, the predominance of $\alpha$ - isomers in all tissues reflects a recent application of the technical mixture in the study area. Availability of OCCs to carp was high for Endosulfan (that represent $63.5 \%$ ) as a combination of its current use and their relative high water solubility (low Kow). However, is known the Endosulfan toxicity for fishes showing symptoms like excessive mucus production and histological lesions in gills, liver and kidney (Nowak, 1992; Capkin et al., 2006; Ballesteros et al., 2007).

Gamma $\mathrm{HCH}$ is the isomer with high solubility water regarding to other isomers (Tanabe et al., 1991) and the unique with insecticide properties, known as "Lindane" (99\% $\gamma-\mathrm{HCH})$. The high levels of $\gamma-\mathrm{HCH}$ found in gills, suggest that the input of this pesticide through respiratory surface would be enhanced by its hydrosolubility.

OCPs and PCBs were detected in water samples from the same studied area in the order of ng. $\mathrm{L}^{-1}$ (Miglioranza et al., 2007). Levels in water were lower than those found in gills, being similar the pesticides distribution pattern in both matrixes. The main groups found in water were Endosulfans ( $>>\alpha$-isomer), HCHs ( $\gamma$-isomer) and Heptachlors (H. epoxide), supporting the hypothesis that, pesticides with lower Kow are available for fishes uptake from water column. Pesticides metabolism occurs by hydrolysis, photolysis and biological degradation. The substantial Endosulfan sulfate, pp'-DDE and Heptachlor epoxide levels found in gills could be attributed to the high metabolic rate in this tissue (Evans et al., 2005), considering the ratio metabolite/parent in gills and water. Although more studies are necessary in order to explain if these metabolites are being produced as a consequence of fish metabolism or are being incorporated directly from the water column.

An important load of contaminants present in the water column are not in the dissolved phase. These pollutant can be adsorbed onto suspended particular matter (SPM) being also available to fish uptake. Several reports document that the load of contaminants present in SPM is higher than those found in bottom sediment (Robinson et al., 2008). Because of this, we compare our gills results with the levels found in SPM from the same place considering the potential risk that represent high OCCs levels (Miglioranza et al., 2007). Thus, OCPs levels in SPM were higher than those in gills with a similar distribution pattern between both matrixes. In agree with the previous statement, these results suggest that both water column and SPM represent sources of OCCs to carps being incorporated across gill membranes. 
Once a contaminant moves from water or sediments into organism, the contaminants can subsequently move through the food chain when contaminated food are ingested (Landrum \& Fisher, 1998). The relative contribution of the dietary pathway is a result of the fish feeding activity, characteristics of the diet and chemical properties of the contaminants. Similar HCHs, DDTs, Chlordanes and PCBs levels were observed in stomach content suggesting that the exposure through food ingestion is important to recalcitrant compounds.

Although, Chlordanes and DDTs use was forbidden 10 years ago (SAGPyA, 1998) high levels of their residues could still be found in the environment due to their long half-life being available for fish accumulation. Besides, fresh DDTs inputs are associated to the use of the acaricide Dicofol which is currently used in our country (INTA, 2004) and present DDT impurity from manufacturing processes (Qui et al., 2005). Moreover, DDT being used with health purposes (Malaria vector control) in equatorial countries could reach the studied zone by atmospheric transport (Moraes et al., 2003). When comparing OCCs residues in stomach content with those detected in Surface Sediments (SS) (ng. ( $^{-1}$ total organic carbon) from a close area (Miglioranza et al., 2008) a similar distribution pattern $(\mathrm{HCHs}>$ DDTs $>$ Chlordane $>$ Endosulfan $>$ PCBs) was observed although levels in carp were lower. This relationship shows the relative contribution of dietary uptake of OCCs considering that common carp feeds detritus and macrophytes.

PCBs concentrations in muscle and liver of common carp from Patagonia are comparable with those found in slightly industrial polluted areas such as Sir Dam Lake in Turkey (Erdrogul et al., 2005). The pattern of PCBs was very similar among tissues, enriched in penta and hexachlorobiphenyls (\# 87, 101, 110, 153 and 138) similar pattern to Arochlor 1254 composition (Breivik et al., 2002) historically used in the region. González Sagrario et al. (2002) and Colombo et al. (1990, 2007) have reported a predominance of these congeners in pelagic as well as benthic fishes from other areas in Argentina, with congener \#153 found in the largest concentrations in biological species (Loizeau et al., 2001). In fact, the PCBs profile found in common carp is in accordance with that reported for freshwaters and marine fishes from other geographical areas (Bayarri et al., 2001; Sanchez et al., 1993; Porte \& Albaigés, 1993).

Regarding to OCCs tissues distribution, liver and muscle had similar total levels suggesting that, common carp from the Negro River support a chronic as well as acute exposition to these contaminants. When BMF was calculated, the higher values were found for Endosulfan $=$ PCBs (7.1) $>$ Chlordanes (2) $>$ Heptachlors (1.5) $>$ DDTs (1.2). It can be explained by the fact that those more hydrophobic contaminants are better biomagnified and the current use of Endosulfans leads to a high environmental exposure of this pesticide with the subsequently high BMF independently of its Kow.

In conclusion, our results showed a substantial predominance of OCPs in all fish tissues reflecting the impact of agricultural activities developed in the study area. Moreover, two clear trends were established, one in gills where slightly hydrophobic groups, like Endosulfans, were more relevant in contrast with stomach content pattern where strongly hydrophobic and persistent contaminants like DDTs and Chlordanes predominated. Therefore, these distributions suggest the uptake of pesticides present in water column, either in dissolved phase or adsorbed to SPM, through respiratory surface of the gills. Conversely, extremely hydrophobic contaminants with higher persistence are being mainly incorporated in carps by food item.

Acknowledgements - The authors thanks to Mr. Guillermo Sanahuja and the authorities of Fishery Direction of Negro River Province, Mrs. Raul Roa, Alberto Escurra, Luis Quiroga, Walter Muñoz and Carlos Campos for their help during the sample collection. This study was supported financially by grants from Mar del Plata National University and PNUD GEF AR/018 BC-42 “Contaminación Marina Patagónica”. This work is part of the PhD. Thesis of the first author.

\section{REFERENCES}

ALVEAR, P. A., RECHENCQ, M., MACCHI, P. J., ALONSO, M., LIPPOLT, G. E., DENEGRI, M. A., NAVONE, G., ZATTARA, E. E., GARCÍA ASOREY, M. I. \& VIGLIANO, P. H., 2007, Composición, distribución y relaciones tróficas de la ictiofauna del Río Negro, Patagonia Argentina. Ecol. Austral, 17: 231-246.

ARRIBÉRE, M. A., RIBEIRO GUEVARA, S., SÁNCHEZ, R. S., GIL, M. I., RÓMAN ROSS, G., DAUDARE, L. E., FAJON, V., HORVAT, M., ALCALDE, R. \& KESTELMAN, A. J., 2003, Heavy metals in the vicinity of a chlor-alkali factory in the upper Negro River ecosystem, Northern Patagonia, Argentina. Sci. Tot. Environ. 301: 187-203. doi: 10.1016/S0048-9697(02)00301-7.

BALlesteros, M. L., BIANCHI, G. E., CARRANZA, M. \& BISTONI, M. A., 2007, Endosulfan acute toxicity and histomorphological alteraltions in Jenynsia multidentata (Anablepidae, Cyprinidontiformes). J. of Environ. Sci. \& Health part B 42: 351-357. doi: 10.1080/03601230701309577.

BAYARRI, S., BALDASSARRI, L. T., IACOVELLA, N., FERRARA, F. \& DI DOMENICO, A., 2001, PCDDs, PCDFs, PCBs and DDE in edible marine species from the Adriatic Sea. Chemosphere 43: 601-610. doi: 10.1016/S00456535(00)00412-4.

BERTELSEN, S. L., HOFFMAN, A. D., GALlinAT, C. A., ELONEN, C. M. \& NICHOLS, J. W., 1998, Evaluation of Log Kow and tissue lipid content as predictors of chemical partitioning to fish tissue. Environ. Toxicol. Chem. 17: 1447-1455. doi: 10.1002/etc.5620170803.

BREIVIK, K., SWEETMAN, A., PACYNA, J. M. \& JONES, K. C., 2002, Towards a global historical emission inventory for selected PCB congeners-a mass balance approach. 1. Global production and consumption. Sci. Tot. Environ. 290: 181-198. doi: 10.1016/ S0048-9697(01)01076-2.

CAPKIN, E., ALTINOK, I. \& KARAHAN, S., 2006, Water quality and fish size affect toxicity of Endosulfán, an organochlorine pesticide, to rainbow trout, Chemosphere 64: 1793-1800. doi: 10.1016/j.chemosphere.205.12.050.

COlOMBO, J. C., CAPPElletti, N., MigoYA, M. C. \& SPERANZA, E., 2007, Bioaccumulation of anthropogenic contaminants by detritivorous fish in the Río de la Plata estuary: 2-Polyhlorinated Biphenyls. Chemosphere 69: 1253-1260. doi: 10.1016/j.chemosphere.2007.05.073.

COLOMBO, J. C., KHALli, M. F., ARNAC, M. \& HORTH, A. C., 1990, Distribution of Chlorinated Pesticides and Individual Polychlorinated Biphenyls in biotic and abiotic compartments of 
the Rio de La Plata, Argentina. Environ. Sci. Technol. 24: 498505. doi: 10.1021/es00074a006.

ELDKUS, A. A., COLliER, T. K. \& MONOSSON, E., 2005, Interactions between lipids and persistent organic pollutants in fish. In: T. P. Mommsen \& T. W. Moon (eds.). Biochemistry and Molecular Biology of Fishes, $6^{\circ}$ vol., Environmental Toxicology, Elsevier Science, St. Louis, chap. 4, p.119-152.

ERDROGUL, O., COVACI, A. \& SCHEPENS, P., 2005, Levels of organochlorine pesticides, polychlorinated biphenyls and polybrominated ethers in fish species from Kahramanmaras, Turkey. Environ. International 31: 705-711. doi: 10.1016/j. envint.2005.01.002.

EVANS, D. H., PIERMARINI, P. M. \& CHOE, K. P., 2005, The Multifunctional Fish Gill: Dominant Site of Gas Exchange, Osmoregulation, Acid-Base Regulation, and Excretion of Nitrogenous Waste, Physiol. Rev. 85: 97-177. doi: 10.1152/ physrev.00050.2003.

FAO/WHO, 2001, Codex Alimentarius Commission, Maximum Residue Limits for Pesticides, FAO/WHO, Rome, Italy.

GERSTENBERGER, S. L., GALLINAT, M. P. \& DELLINGER, J. A., 1997, Polychlorinated biphenyl congeners and selected organochlorines in Lake Superior fish, USA. Environ. Toxicol. Chem. 16: 2222-2228. doi: 10.1002/etc.5620161104.

Gobierno de Río Negro, Secretaria General de la Gobernación, [s.d.], Sistema Provincial de Información. Available from: $<$ http://www. spi.rionegro.gov.ar/>. Access in: 15 Apr. 2008.

GONZÁlez SAGRARIO, M. A., MIGLIORANZA, K. S. B., AIZPÚN, J. E., MORENO, V. J. \& ESCALANTE, A. H., 2002, Polychlorinated biphenyls in different trophic levels from a shallow lake in Argentina. Chemosphere 48: 1113-1122. doi: 10.1016/S0045-6535(02)00149-2.

INTA, Instituto Nacional de Tecnología Agropecuaria, 2004, Guía de pulverizaciones para cultivos de manzano, peral, frutales de carozo y vid, $5^{\text {th }}$ ed., INTA, Estación Experimental Agropecuaria Alto Valle, Centro Regional Patagonia Norte, p. 132.

LANDRUM, P. F. \& FISHER, S. W., 1998, Influence of lipids on the bioaccumulation and trophic transfer of organic contaminants in aquatic organisms. In: M. Arts \& Wainman B. (eds), Lipids and Freshwater Ecosystems, New York, chap. 9, p. 203-234.

LOIZEAU, V., ABARNOU, A., CUGIER, P., JAOUENMADOULET, A., LE GUELLEC, A. M. \& MENESGUEN, A., 2001, A model of PCB Bioaccumulation in the sea bass food web from the Seine Estuary (Easter English Channel). Mar. Poll. Bull. 43: 242:255. doi: 10.1016/S0025-326X(01)00082-0.

MACKAY, D. \& FRASER, A., 2000, Bioaccumulation of persistent organic chemicals: mechanisms and models. Environ. Poll. 110: 375-391. doi: 10.1016/S0269-7491(00)00162-7.

METCALFE, T.L.\& METCALFE, C. D., 1997, The trophodynamics of PCBs including mono and non-ortho congeners in the food web of north-Central Lake Ontario. Sci. Tot. Environ. 201: 245272. doi: 10,106/S0048-9697(97)84061-2.

MIGLIORANZA, K. S. B, AIZPÚN, J. E. \& MORENO, V. J., 2003, Dynamics of organochlorine pesticides in soils from a SE region of Argentina. Environ. Toxicol. Chem. 22: 712-717. doi: 10.1002/ etc. 5620220405 .
MORAES, R., ELFVENDAHL, S., KYLIN, H. \& MOLANDER, S., 2003, Pesticides residues in rivers of a Brazilian Rain Forest Reserve: assessing potential concern for effects on aquatic life and human health. Ambio 32: 258-263.

NOWAK, B., 1992, Histological changes in gills induced by residues of Endosulfan. Aq. Toxicol. 23: 65-84. doi: 10.1016/0166445X(9290012-C.

NOWAK, B., GOODSELL, A. \& MORENO, J., 1995, Residues of Endosulfan in carp as an indicator of exposure conditions. Ecotoxicology 4: 363-371. doi: 10.1007/BF00118871.

PORTE, C. \& ALBAIGÉS, J., 1993, Bioaccumulation patterns of hydrocarbons and polychlorinated biphenyls in bivalves, crustaceans and fishes. Arch. Environ. Contam. Toxicol. 26: 273281. doi: 10.1007/BF00203552.

QUI, X., ZHU, T., YAO, B., HU, J. \& HU, S., 2005, Contribution of dicofol to the current DDT pollution in China. Environ. Sci. Technol. 39: 4385-4390. doi: 10.1021/es050342a.

ROBINSON, S. D., LANDRUM, P. F., VAN HOF, P. L. \& EADIE, V. J., 2008, Seasonal variation of polichlorinated biphenyl congeners in surficial sediments, trapped settling material and suspended particulate material in Lake Michigan, USA. Environ. Toxicol. Chem. 27: 313-322. doi: 10.1897/07-006R.1.

SAGPyA, Secretaria de Agricultura Ganadería, Pesca y Alimentos, 1998, Secretaria de Agricultura Ganadería (SAGPyA), Ministerio de la Producción de la República Argentina, Resolución 513/98. Available from: <http://www.sagpya.mecon.gov.ar/.> Access in: 15 Apr. 2008.

SÁNCHEZ, J., SOLÉ, M. \& ALBAIGÉS, J., 1993, A comparison of distributions of $\mathrm{PCB}$ congeners and other chlorinated compounds in fishes from coastal areas and remote lakes, Int. J. Environ. Anal. Chem, 50: 269-284. doi: 10.1080/03067319308027603.

SCHMIDT, W., HAPEMAN, C., FETTINGER, J., RICE, C. \& BILBOULIAN, S., 1997, Structure and asymmetry in the isomeric conversion of $\beta$ - to $\alpha$ - endosulfan, J. Agric. \& Food Chem. 45: 1023-1026. doi: 10.1021/jf970020t.

SZAREK, J., SIWICKI, A., ANDRZEJEWSKA, A., TERECHMAJEWSKA, E. \& BANASZKIEWICZ, T., 2000, Effects of the herbicide Roundup ${ }^{\mathrm{TM}}$ on the ultrastructural pattern of hepatocytes in carp (Cyprinus carpio), Mar. Environ. Res. 50: 263-266. doi: 10.1016/S0141-1136(00)00088-X.

TANABE, S., RAMESH, A., SAKASHITA, D., IWATA, H., TATSUKAWA, R., MOHAN, D. \& SUBRAMANIAN, A. N., 1991, Fate of $\mathrm{HCH}$ (BHC) in tropical paddy field: application test in South India, Int. J. Environ. Anal. Chem. 45: 45-53. doi: $10.1080 / 03067319108232937$.

VAN DER OOST, R., LOPES, S. C. C., KOMEN, H., SATUMALAY, K., VAN DEN BOS, R., HEIDA, H. \& VERMEULEN, N. P. E., 1998, Assessment of environmental quality and inland water pollution using biomarker responses in caged carp (Cyprinus carpio): use of a bioactivation: detoxification ratio as a biotransformation index (BTI), Mar. Environ. Res. 46: 315-319. doi: 10.1016/S0141-1136(97)00096-2.

ZAR, J. H., 1984, Biostatistical Analysis, $2^{\text {th }}$ ed. Prentice-Hall International Inc., London, 718p. 
